\title{
A New Model of Coping for Mothers of Young Children
}

\author{
Janet L Currie* \\ University of Technology Sydney, Australia
}

Submission: November 19, 2018 ; Published: November 26, 2018

*Corresponding author: Janet L Currie, University of Technology Sydney, Australia

Keywords: Mothers; Coping; Coping Strategies; Wellness; Health; Managing Motherhood; Subjective Wellbeing

\section{Introduction}

Coping includes those efforts an individual uses to deal with a stressful situation. Effective coping requires an individual to utilise strategies which help them solve and overcome the perceived problem. Women often say coping with the new period of motherhood can be a stressful time due to the lifestyle changes, challenges and tiredness created through caring for the new baby. However, while most mothers in the general population identify as feeling well during this period, the bulk of the coping research literature actually deals with minority groups, illness and the unhealthy process of 'not coping'. In fact, coping has had a 'bad rap' as being characterised as tolerating or 'putting up' with situations, not something we can necessarily gain health and wellbeing from. In this Opinion article, I argue for a new wellness model of coping to represent what healthy coping means for mothers identifying as well during this period.

\section{What is Coping?}

Coping strategies used by mothers of young children is an important area to explore because feeling in control of one's environment has important consequences for health, well-being, and feelings of confidence and adequacy in the motherhood role. Past research has also demonstrated that anxious mothers are less satisfied with quality of life and their motherhood role.

According to my research, mothers state that for them, coping includes a feeling of control of one's situation. This is consistent with a health-promoting theoretical context whereby people are able to sense increased control over their own health and lifestyle. Ironically, women may be less aware of when they are coping more effectively, as it can feel as though they are on 'auto-pilot'. However, coping enhances a mother's satisfaction level in her role.

Mothers consistently express how coping with motherhood is up to them. While they utilise basic coping strategies such as having a routine, asking for help or trying some time-out, if a mother doesn't take control of the household, there is no-one else mentioned as taking charge or full responsibility. Effective coping and 'household management' was an area of the mothers' lives which mattered a great deal to them. Choice of strategy was strongly influenced by mothers being highly aware of not inconveniencing the other party. In deciding whether to accept any form of assistance, a mother will consider the potential reciprocal obligation or social pressure to offer some sort of comparable help in return. Coping independently by one's self is rated as the most preferred strategy. While there are hidden social pressures for women to appear as though they are coping with the motherhood role, most women can honestly reveal how difficult it can be. Who is going to care for or nurture the carer?

\section{A New Wellness Model}

From a wellness perspective, effective coping depends on an individual's personal evaluation of the situation. While much of the existing research on women's mental health has not clarified the nature of the coping experience from a subjective wellness perspective, nor taken a grounded theory approach using the participant's own words and meanings to describe the experience, it is hoped that my latest book [1], will help to challenge current prevailing negative, illness-based approaches to coping with a positive, subjective wellness model. In it, I provide enlightenment on the meaning of the positive coping experience for new mothers. The experiences described by the women reflect universal health promotion principles. These highlight the importance of subjective wellness and increasing control over one's own health within one's day-to-day lifestyle.

Mothers in general describe their home environment as busy and challenging. Each mother can usually nominate at least one method with which she attempts to deal with a stressful situation. In a positive cycle, mothers discovering a successful coping strategy consequently felt greater confidence in the efficacy of her selected method, calmer, and in greater control of her personal situation. A self-perception of dealing effectively with a 
situation, pressure, or scenario was described by the mothers in my research as resulting in a perceived sense of wellness. In order to achieve a true sense of increasing control over her own health, however, it is recommended a mother further prioritize strategies for meeting her own individual needs in addition to meeting the needs of others.

\section{Conclusion}

The period of early motherhood can represent a period of great stress, change and personal demands within a woman's life. Coping strategies or personal efforts, subjectively evaluated as being effective, usually result in an individual feeling a greater sense of control. Successful coping contributes to an overall sense of social competence or self-esteem, which may positively affect health and resilience. Prior to my new book, Managing Motherhood, there were no scholarly books available analysing coping from a positive, wellness perspective. Coping strategies or personal efforts, subjectively evaluated as being effective, usually result in an individual feeling a greater sense of control. It is important for health and medical practitioners to promote a new resilience model of health and well-being for mothers because successful coping contributes to an overall sense of social competence or self-esteem, which may positively affect health.

\section{References}

1. Currie JL (2018) Managing Motherhood. A new wellness perspective. Springer, Singapore.

\section{Your next submission with Juniper Publishers} will reach you the below assets

- Quality Editorial service

- Swift Peer Review

- Reprints availability

- E-prints Service

- Manuscript Podcast for convenient understanding

- Global attainment for your research

- Manuscript accessibility in different formats ( Pdf, E-pub, Full Text, Audio)

- Unceasing customer service

Track the below URL for one-step submission https://juniperpublishers.com/online-submission.php 